\title{
PROJECT-BASED LEARNING TO DEVELOP STUDENTS' ABILITY AND CREATIVITY IN WRITING NARRATIVE STORY
}

\author{
Eva Fitriani Syarifah \\ English Education Department, Faculty of Teacher Training and Education, \\ Universitas Majalengka, Indonesia \\ E-mail: eva.fsyarifah@gmail.com \\ Raynesa Noor Emiliasari \\ English Education Department, Faculty of Teacher Training and Education, \\ Universitas Majalengka, Indonesia \\ E-mail: raynesanoor@gmail.com
}

APA Citation: Syarifah, E. F., \& Emiliasari, R. N. (2018). Project-based learning to develop students' ability and creativity in writing narrative story. Indonesian EFL Journal, 5(1), 8594. doi: 10.25134/ieflj.v5i1.1627.

Received: 22-09-2018

Accepted: 29-11-2018

Published: 01-01-2019

\begin{abstract}
In English language teaching, project-based learning is not only able to optimize language skills but also other skills such as critical and creative thinking. This study tries to investigate the use of project-based learning to develop students' abilities and creativity in writing narrative text and the students' perception towards the implementation of project-based learning in writing course. This study employed a qualitative approach by involving second semester students who take writing course. The results of this study indicated that project-based learning can help the students to develop their ability and creativity in writing narrative text in several point including their understanding of the topic, their knowledge about narrative genre namely social function, structure of text, and language feature. In addition, the students also showed their creativity through creating their story line and designing the illustration of the story. Furthermore, the students gave positive views toward the implementation of project-based learning. They mentioned that they learned networking, collaborative learning, and team work through PBL. Thus, projectbased learning can be one of alternative ways to teach writing in higher education.
\end{abstract}

Keywords: narrative text; project based learning; student creativity; teaching writing; writing skills.

\section{INTRODUCTION}

Writing is an essential skill that should be well mastered by students in higher education. Through writing, students are able to convey their thoughts and communicate their ideas. In addition, writing can foster students' creativity and critical thinking. Moreover, writing skill is important because it determines students' ability and success in learning English.

However, based on the preliminary observation conducted at English education study program where researchers teach, among four English language skills, writing is a skill that is challenging to master by the students. From the results of interviews with some students, it can be concluded that the factors that cause students' difficulties in writing an English essay are lack of understanding of the topic, the purpose of writing, and how to organize ideas into writing. This is in line with Walker and $\mathrm{R}_{1}{ }^{\prime} \mathrm{u}$ (2008) who mention that many of the language learners are lack of confidence and interest in writing. In addition, lack of feedback from lecturers also influenced low enthusiasm of students in writing.

Dealing with the problems described above, a solution is needed to facilitate the students to develop their ability and 
creativity in writing. In this study, narrative essay becomes the focus of students' writing. Narrative essay is chosen based on the level of complexity since the participants of this study are the second semester students who can be categorized as beginners. The purpose of narrative is to entertain the reader or listener through the stories conveyed (Derewianka \& Jones, 2012). Considering the advantages and disadvantages which have been explained by some researchers, such as Andrea and Florica (2013), Bell (2010), and Castaneda (2014), project-based learning (PBL) can be an alternative that is possibly used to solve problem in writing.

Project-Based Learning has been applied in teaching and learning process in various levels of education in various countries, such as Malaysia, Australia, Singapore and America. The implementation of projectbased learning is able to facilitate students in developing certain skills such as writing, providing learning processes that can be significantly beneficial for students, increasing creativity and motivation, and increasing discipline and collaboration of students (Syahmadi, 2014).

Project-based learning (PBL) is a learning method that emphasizes students to deal with real issues and problems that are useful for them (Fragoulis, 2009). In the learning process, projects or activities are used as media (Bell, 2010). Here, learners explore, evaluate, interpret, synthesize, and convey information about the project carried out. Project-based learning is an activity carried out in the long term, studentcentered, and integrates real problems and practices.

In Project based-learning, students acquire knowledge and skills through collaboration in an agreed period of time to produce a real product and then present it. Project-based learning makes it possible for teachers or lecturers to conduct authentic assessments during learning and project activities (Collier, 2017). This is advantageous for the teacher or lecturer to assess the ability of students as a whole and conduct evaluations to improve subsequent learning activities.

In general, project-based learning is divided into three stages namely planning, implementing, and presenting (Educational Technology Division, 2006; Essien, 2018; Kalabzová, 2015). In planning stage, students are divided into groups then choose topics, conduct literature studies, look for sources of information needed, and arrange the resources needed. Then, during the implementation, the students develop project ideas, collect data, share roles in groups, and carry out projects. Last, the students in group presents the results of their project, and then the feedback obtained is used as individual reflection.

Fragoulis (2009) and Bell (2010) mention that there are many benefits that can be obtained from the application of projectbased learning in teaching English as a foreign language, including; 1) providing useful learning and, in accordance with student needs, project-based learning produces products that benefit students in real contexts. What is produced by them can be used in their lives in accordance with the field of study; 2) creating optimal conditions for students to improve their English skills. Project-based learning can help students to optimize English language skills comprehensively. Not only writing, but also other language skills, such as speaking can be optimized when they present the final results of their project; 3) facilitating students to be actively involved in projects designed. Students are required to be active in completing projects and learning activities so that no students are expected to be passive and apathetic; 4) increasing interest and motivation in learning English that is fun projects are carried out based on the interests and agreement of students and lecturers so that students are expected to complete the project voluntarily; and 5) improving the ability to work together since the project is done together so that good cooperation is expected between students.

Basically, there have been studies concerning the implementation of project- 
based learning which conducted by Hasani, Hendrayana, and Senjaya (2017), Larasati (2015), and Zaki and Rosa (2014). The studies showed that project-based learning enables students to improve their writing skills. Hence, this study tries to investigate whether project-based learning can help students in higher education to develop their ability and creativity in writing. Furthermore, it also tries to explore students' perceptions towards the implementation of project-based learning in writing course.

\section{METHOD}

This study is a qualitative study which can be specifically categorized as qualitative research evaluation program. As explained by Emilia (2005), in this type of study, the researcher acts as designer and implementer of learning activities. Thus, in this study, the researcher was the lecture who designed the teaching and learning program and implemented the project-based learning in writing course.

This study was conducted at a private university in Majalengka, West Java. The site was chosen because the researchers were teaching staffs at the University so that the results of this study were expected to make a real contribution to better learning activities. The participants of the study were the second semester students of the English language education study program who take writing course.

The data were obtained through field note, final product of the project, and interview. Field notes were used to get data about learning activities, especially to see the development of students' abilities in writing and working on projects. Then, interviews were conducted twice, at the beginning and at the end of the learning activity to find out the students' prior knowledge about narrative essay and students' perception regarding the implementation of project-based learning in writing course. Last, the final product of the project was the final result developed by students. The final project was a book containing narrative stories written by students in groups.

The data gathered from the field notes were coded, categorized, and interpreted. Then, the obtained data from the diagnostic test and final product of the project were analyzed by using genre analysis which includes the element of narrative essay. Last, the results of interview were transcribed then coded, categorized, and interpreted.

\section{RESULTS AND DISCUSSION}

There are two issues covered in the analysis, namely; 1) the development of students' ability and creativity in writing narrative essay during the implementation of projectbased learning, and 2) the students' perception towards the implementation of project-based learning. With regards to the development of students' ability and creativity in writing narrative essay during the implementation of project-based learning, there are several main points covered, namely students' understanding about the topic, students' knowledge about narrative genre namely social function, structure of text, and language feature. In addition, the students also show their creativity through creating their story line and designing the illustration of the story. Furthermore, the students give positive views toward the implementation of projectbased learning. They mentioned that they learned networking and collaborative learning through PBL.

\section{Students' ability and creativity in writing narrative essay}

With regards to the development of students' ability and creativity in writing narrative essay during the implementation of projectbased learning, there are several main points covered, namely; 1) students' understanding about the topic, 2) students' understanding about the social function of narrative essay, 3) students' understanding about the structure of narrative essay, and 4) students' understanding about the language feature of narrative essay. In addition, related to students' creativity, there are two points highlighted in this study, namely; 1) creating 
story line and 2) designing the illustration of the story.

During the implementation of projectbased learning in teaching writing, there are ten activities done. First, students and lecturer agreed on the theme of the project to be implemented. The theme is adjusted to the learning material being discussed or based on the syllabus. Besides, themes can also be chosen based on students' interest. Second, students and lecturer determined the final outcome of the project. At the beginning of the project, after determining the theme, the final results of the project must also be determined, such as what projects will be made by students and the benefits of the project. Then, students and lecturers drew up the project's framework which includes drafting the framework of the project and making a timeline for each activity that must be achieved. Fourth, lecturers helped students to map the collection of information needed. In projectbased learning, information is the main source for project completion. Therefore, the lecturer or teacher must accompany students in mapping information that is needed for the project. Fifth, students collected necessary information regarding the project. In this case, information related to the project must be collected as much as possible so that the project can run smoothly without lack of information or reference sources. The lecturer prepared students to compile and analyze data. The lecturer provided direction to compile and analyze data based on information or data that has been obtained. Next, students compiled and analyzed data and information obtained. Data and information that have been obtained were used to complete the project. Students then chose information and data to be used. Eight, the lecturer prepared students for the final activity. Lecturers and students discussed the final project activities. It includes what would be done next or would the results be presented or made as exhibition depending on mutual agreement after the project was completed. Then, students presented the final results of the project. Students presented the final results of the project so that they could show their knowledge about the project that has been done. In addition, other aspects of skills could be seen when students present the final project. Last, students evaluated projects that have been implemented. In project-based learning, students were required to evaluate the project that has been done. This was useful for them going forward, they could find out the shortcomings. In addition, the evaluation process was also be used as a reference by lecturers to improve the future teaching and learning process.

\section{Understanding and developing topic}

Based on the result of preliminary study, one of the problems mostly faced by the students in writing an essay was developing topic. Some of them seemed to misunderstand several topics given. They did not have prior knowledge about the topic and did not know how to develop the topic. Therefore, as what have been mentioned by Emilia (2011), asking students to explore more about the topic will be very useful for them.

During the implementation of projectbased learning, the students were encouraged to explore the topics that they are going to write. In this study, the topics were related to narrative story which include folklore, fairytale, fable, myth, legend, and others. Thus, the students were asked to find information as many as they can, relating to folklore, fairytale, myth, fable, and legend. Then, after they have understood about each of them, they needed to select a category that most interesting for them.

The project was accomplished in a group. Thus, the students were grouped based on their interest. After that, all of the students and lectures discussed about the final product of the project. Then, it was determined that the final product of the project would be a story book for young learners. The story presented should reflect good moral values and originally from Indonesia. The stories written by the students were mostly fable and legend. Some of the stories written by them were "The Legend of Rawa Pening", "The Rabbit and 
The Turtle", "The Grasshopper", and "The Stupid Dog”.

The results drawn from the interviews before and after the implementation of project-based learning indicated that students understand the topic that they were going to write. It was because they tried to explore more information and data about the topic before they started writing. They selected the data and information that they needed. Thus, they can be able to have a good prior knowledge related to the topic. In the final product of the project, it can be seen that story book created by the students can be understood by others. This was proven during the presentation and evaluation session of the project where each group presented their book and it was well appreciated by others. Below are the excerpts taken from the interviews with the same student before and after the implementation of PBL.

Student's answer from interview before PBL

Excerpt\#1

$\mathrm{R}$ : "What do you know about narrative?"

$\mathrm{S}$ : "Narrative is about fiction. The story is not real and fantasy."

Student's answer from interview before PBL

Excerpt\#2

$\mathrm{R}$ : "What do you know about narrative?"

$\mathrm{S}$ : "Narrative is one of the genres that used to amuse the reader. The stories can be about legend, fairytale, myth, fable, and folklore."

The excerpts indicate that after the project was accomplished, the student knew narrative genre better than before. The students can create the stories well because they know the topic. They understand what should be developed in the stories, how the stories go on, and how to open the stories, create the conflict, give the resolution, and others.

\section{Understanding the purpose or social function of narrative genre}

Knowing the purpose of our writing is very important because it leads direction for us as the writer where we are going to. In this study, the purpose or social function of narrative texts was discussed by the students and lecture during collecting comprehensive data on narrative story. The students were not told explicitly about the purpose of narrative genre but they explored by themselves. In the beginning, most of the students did not know the purpose of narrative. Some of them mentioned the purpose is to describe, to tell, or to explain a story. However, in the final results of the project, the stories developed by students have fulfilled the social function of a narrative text that is to entertain the reader. This is supported by data obtained from interviews where students can explain well about the social function of a narrative text.

Excerpt\#3

$\mathrm{R}$ : "Do you think that your story fits for young learners?"

S : "Yes, because I think, the elementary students or children who read our book story will be happy.

$\mathrm{R}$ : "Why do you think so?"

$\mathrm{S}$ : "They will enjoy reading because the story that we made is easy to understand. And illustrations support the story and the kids will love it."

The excerpt shows that the students know the target readers so they create the story based on the characters of the readers. In this study, the stories written by the students were dedicated for young learners.

\section{Understanding the structures of narrative genre}

As what have been explained by Derewianka and Jones (2012) and Martin and Rose (2008), the structure of a narrative genre consists of orientation, complication, and resolution. Based on the results of the interview in the beginning of this study, there were still many students who did not know the structure of a narrative genre. The story books that they have written reflect their understanding of the structures of narrative story. The stories consist of what a narrative should be. It consists of orientation, complication, and resolution. Some of stories were also added by moral values. Some of students show their understanding during the interview session.

Excerpt\#4

$\mathrm{R}$ : "What makes it difference, your understanding about the structures of narrative after this project?"

S : "After this project, I know many about narrative genre. Before, I do not care about the organization of it. " 
$\mathrm{R}$ : "So, what are the structures of narrative?"

S : "Well, it should consist of orientation, complication, resolution."

$\mathrm{R}$ : "Can we have more than one complication in a story?"

S : "Yes, of course we can."

The excerpt shows that the students know the structure of a narrative text that makes it different from other genres. Knowing and understanding the structure of genre is important to make a correct writing.

\section{Understanding the language features of narrative genre}

The result drawn from the interview before the implementation of project-based learning showed that most of the students did not know the language feature of narrative text. Some of them did not realize when they were asked to write some sentences as a part of narrative. They used present tense and did not use relevant conjunction. During writing the draft of story line, it was also found that the students needed time to learn more. Therefore, feedbacks were really important. Feedbacks were given by the lecture and peer.

The storybooks created by the students indicate that the students have learned more about language features of narrative genre. They used simple past tense. They selected suitable conjunction to link the story lines. For example, in the orientation, they used "once upon a time", "long time ago", or "one day" to begin the story. To continue the story they use "then", "after that", and others. Some examples can be seen in the following excerpts.

Excerpt\#5

However, he was expelled by the villagers. All the people there were laughing at him and threw stones at him.

Excerpt\#6

Finally, the whole village turned into a large lake known as Rawa Pening.

Excerpt\#7

In the middle of the journey the rabbit was so exhausted then he leaned on a tree with thick grass and he fell asleep there. While the turtle continued his journey until he reaches the finished line.

In the excerpts, the italics words show the example of conjunction and the underlined words show the example of past tense that exist in students' works. Previously, in writing their draft, the students still used simple present. However, after revising for several times, the stories reflect their understanding to use appropriate tenses in writing narrative stories.

\section{Creating Story Line}

Writing becomes difficult for most of the students when they were asked to write long essay. However, in this project, they were asked to write a children book story. They were asked to create a good story line in each page. In the beginning, when the students were asked to write a draft, some groups write the story line in a long paragraph which consists of complicated sentences. The example can be seen in the following excerpt.

\section{Excerpt\#8}

A long time ago, a Mouse Deer lived on the edge of the forest. The mouse deer liked to eat fruits, roots and branches. But he preferred vegetables at the farmer's field. One day the Mouse Deer went into farmers' field. He saw cucumbers that were ready to be picked. He immediately took one and ate it. Then he saw the farmer stared at him. The mouse deer tried to escape but his feet hit the snare. The mouse deer struggled but he failed to escape. The mouse deer laid down on the ground and pretended to be dead.

This paragraph was written in a page. The paragraph is quite long for elementary school students. Therefore, after several revisions through feedback from their peers and lecturer, they can do better.

\section{Excerpt\#9}

A long time ago, a mouse deer lived in the forest. He likes to eat and vegetables fruits. He took the vegetables from the farmer's field.

Those excerpts gave examples of story lines that created by the students. For the students, it was not easy to create the story line but still they enjoyed the process. The students were find difficulties to link the story from one to other pages.

\section{Designing illustration}

In the project, the students were agreed to make their own illustration manually. Thus, they need to make illustration based on the story in each page. Some of the students are good at drawing but some of them were not. However, they worked together to create the best illustration based on their own. All of 
the students' works meet their expectation. Some of the students thought that they became more creative because they need to create the illustration that meet the story line.
They were all satisfied with the final product of the project. Here are some examples of the illustration on the students' works.

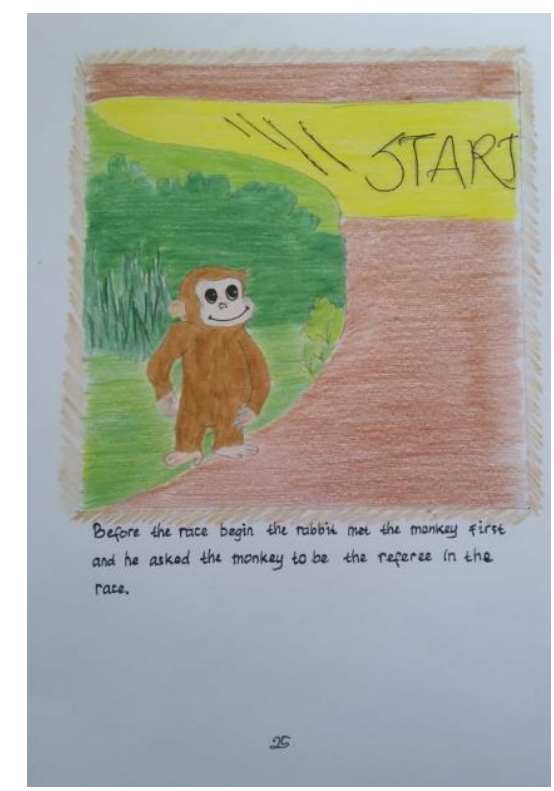

Figure 1. Examples of the illustration on the students' works

The examples show that the students tried to write children friendly story. They create colorful illustrations that explain the story lines in each page. In the interview, the students were asked about how they got the inspiration for the illustration. They mentioned that they discussed together with the members of the group. They shared their ideas so it became the draft. Then, they tried to revise it for several times to make it better.

\section{Students' perception towards the implementation of project-based learning in writing course}

The results of the interview which was conducted after implementing project-based learning indicate that almost all students gave positive responses. They argued that working on projects was more fun because they could determine the final project output based on their interest and agreement. In addition, project that accomplished in groups can ease their difficulties, increase collaboration in groups, and share roles according to the strengths of each member. In other words, through project-based learning, they learn networking and collaborative work in joyful teaching and learning process. This in in line with Kimsesiz, Dolgunsöz, and Konca (2017) who mentioned that project-based learning promotes students' active involvement and cooperation during the teaching and learning process. The students' perception towards the implementation of project-based learning can be seen in the following excerpt.

\section{Excerpt\#10}

"I enjoy work in project because I can do the project together with friends. We can share our idea. If I cannot do "A", the member of the group will help. For me, it really helps me because I cannot learn alone."

Excerpt\#11

"Doing project is fun. I can do better. I understand the steps. I like work together. I like project better than written test."

Excerpt\#12

"This project is cool. Someday I want to be a children story writer. I love drawing and writing the story line. It makes me happy"

The excerpts indicate that the students were really enjoyed doing the project. Through the project, they learned networking, collaborative learning, and team work. In addition, they did not feel alone to 
accomplish the project. They can share their ideas, they can argue to each other, and so on.

Moreover, students thought that projectbased learning has a significant impact on developing their ability and creativity in writing narrative essay. In terms of writing skills, they acknowledged that there was an increase in their understanding of the topics they write, social functions, structures, and linguistic features of narrative essay. This is also supported by Larasati (2015) who mentions that applying project-based learning in teaching writing can help the students to improve their writing ability. In addition, in developing the projects they agreed on, students were required to be creative in presenting stories through the illustrations they made so that the target readers who were elementary school students or junior high school students could better understand the contents of the story.

\section{CONCLUSION}

From the analysis, it can be concluded that project-based learning contributes positively to the development of students' ability and creativity in writing. In terms of students' ability, it can be concluded that there are some aspects that are developed after implementing project-based learning which include students' understanding of the topic, the purpose, the structures, and the linguistic features of narrative genre. Then, in terms of creativity, the students reflect their creativity through creating story line and designing illustrations. The students argued that it was not easy to create the illustration that fit to the story line. However, they can do it well because they share and discuss together in group. Moreover, related to students' perception towards the implementation of project-based learning in writing course, it received positive responses from students. Most students tend to prefer the final test in the form of project rather than the written test. Besides, they mentioned that they learn more about networking, collaborative learning, and team work through projectbased learning. Then, some students who were reluctant and assume that they were not good in writing can share and discuss well during the project. They did not feel like left behind by others. Thus, project-based learning is very useful in teaching and learning writing. Hence, it can be an alternative method that can be implemented either by lecturers or teachers in the process teaching and learning writing.

\section{ACKNOWLEDGEMENT}

We would like to extend our sincerest gratitude to DPRM Kemeristekdikti for fully funding this research, to English Education Study Program of Majalengka University that has always been supportive so that this study could be done, and also to the first year students who participated in this study.

\section{REFERENCES}

Andrea, P., \& Florica, M. (2013). Project-based learning in technical higher education. Applied Mechanics and Materials, 371, 739-743.

Bell, S. (2010). Project-based learning for the 21st century: Skills for the future. The Clearing House, 39-43. doi: 10.1080/00098650903505415.

Collier, L. D. (2017). Using a project-based language learning approach in the high school Spanish classroom: Perceived challenges and benefits. Brigham Young.

Derewianka, B., \& Jones, P. (2012). Teaching language in context. Oxford: Oxford University Press.

Educational Technology Division. (2006). Projectbased learning handbook: Educating the millennial learner. Kuala Lumour: Ministry of Education Malaysia.

Emilia, E. (2005). A critical genre-based approach to teaching academic writing in a tertiary EFL context in Indonesia. Melbourne: University of Melbourne.

Emilia, E. (2011). Pendekatan genre based dalam pengajaran bahasa Inggris: Petunjuk bagi guru. Bandung: Rizqi Press.

Essien, A. M. (2018). The effects of project-based learning on students' English language ability (pp. 438-443). The 2018 International Academic Research Conference, Vienna.

Fragoulis, I. (2009). Project-based learning in the teaching of English as a foreign language in Greek primary schools: From theory to practice. English Language Teaching, 2(3), 113-119.

Hasani, A., Hendrayana, A., \& Senjaya, A. (2017). Using project-based learning in writing an 
Indonesian EFL Journal (IEFLJ)

Volume 5, Issue 1, January 2019

educational article: An experience report. Universal Journal of Educational Research, 5(6), 960-964.

Kalabzová, M. (2015). The application of project based learning in the English classrooms. University of West Bohemia.

Kimsesiz, F., Dolgunsöz, E., \& Konca, M. Y. (2017). The effect of project based learning in teaching EFL vocabulary to young learners of English: The case of pre-school children. International Journal of Languages' Education and Teaching, 5(4), 426-439.

Larasati, A. (2015). Improving students' writing skills through project-based learning technique at grade XI of SMAN 2 Sleman in the academic
p-ISSN 2252-7427, e-ISSN 2541-3635

https://journal.uniku.ac.id/index.php/IEFLJ/index

year of 2014/2015. Yogyakarta state university, yogyakarta.

Martin, J. R., \& Rose, D. (2008). Genre relations, mapping culture. London: Equinox Publishing Ltd.

Syahmadi, H. (2014). Bedah curriculum 2013 bagi guru bahasa Inggris. Bandung: Cv. Adoya Mitra Sejahtera.

Walker, R., \& Ri'u, C. P. (2008). Coherence in the assessment of writing skills. ELT Journal, 62, 18-28. doi: 10.1093/elt/ccm074.

Zaki, A., \& Rosa, R. N. (2014). using project based learning in teaching writing a procedure text to senior high school students. JELT, 2(2), 1-7. 
Eva Fitriani Syarifah \& Raynesa Noor Emiliasari

Project-based learning to develop students' ability and creativity in writing narrative story 